\title{
Leucine-Rich Repeats and Immunoglobulin-Like Domains Protein 3
}

National Cancer Institute

\section{Source}

National Cancer Institute. Leucine-Rich Repeats and Immunoglobulin-Like Domains

Protein 3. NCI Thesaurus. Code C101448.

Leucine-rich repeats and immunog lobulin-like domains protein 3 (1119 aa, 123 kDa) is encoded by the human LRIG3 gene. This protein may be involved in signal transduction. 